\title{
KAJIAN ANALISIS WACANA KRITIS PADA CERITA BERGAMBAR ANAK DWI BAHASA KURA-KURA SI PENJAGA SAMUDRA (TURTLE THE GUARD OF THE OCEAN)
}

\author{
Oleh: \\ Agung Praseyo Wibowo \\ Dosen di Universitas Gunadharma; \\ E-mail: agungpwpw @gmail.com
}

\begin{abstract}
Abstrak
Tulisan ini menyajikan kajian wacana kritis terhadap cerita bergambar bilingual Kura-Kura Si Penjaga Samudra. Investigasi kritis itu difokuskan pada kekuatan bahasa pada tataran mikro dan makro terhadap tokoh kura-kura. Hasil penelitian menunjukkan bahwa penulis mencampur adukan habitat, kemampuan maupun bentuk dan istilah dalam cerita agar mempermudah anak-anak dalam mengenal hewan yang termasuk dalam ordo Chelonians ini. Karena memang untuk membedakan ketiga jenis hewan tersebut dirasa cukup sulit untuk anak kecil.
\end{abstract}

Kata Kunci: analisis wacana, makro, mikro, olah bahasa, kura-kura

\section{PENDAHULUAN}

Karya sastra merupakan hasil cipta karya manusia melalui proses pemikiran dan pengolahan. Sastra menggambarkan kehidupan suatu masyarakat, bahkan sastra menjadi ciri identitas suatu bangsa. Sastra bukanlah alat penyampaian wejangan-wejangan atau pendidikan semata, sastra merupakan jalinan antara keduanya. Sebagai karya fiksi, yang ingin dikomunikasikan oleh setiap sastra ialah perasaan-perasaan dan bukan pengetahuan (Suhariyanto, 1982: 14). Karya sastra fiksi bisa disebut sebagai kehidupan buatan (Nurgiyantoro, 2010: 2). Kehidupan di dalam karya sastra adalah kehidupan yang telah diwarnai oleh sikap penulisnya, latar belakang pendidikannya dan keyakinannya. Karya sastra fiksi menceritakan berbagai masalah kehidupan manusia dalam berinteraksi dengan lingkungan, berinteraksi dengan diri sendiri dan berinteraksi dengan Tuhan. Fiksi merupakan penghayatan dan perenungan secara menyeluruh, perenungan terhadap hakikat hidup dan kehidupan, perenungan yang dilakukan dengan penuh kesadaran.

Dongeng merupakan salah satu karya fiksi. Pengarang membuat cerita dalam bentuk dongeng berdasarkan imajinasinya dan pengamatanya terhadap kehidupan. Dalam sebuah kajian karya sastra, pengarang harus memfokuskan perhatiaan pada aspek-aspek tertentu dari karya sastra, misalnya mengenai moralitas dan estetika masyarakat. Ajaran moral merupakan unsur dari sebuah karya sastra fiksi. Secara garis besar persoalan hidup dan kehidupan manusia dibedakan ke dalam persoalan hubungan manusia dengan diri sendiri, hubungan 
manusia dengan manusia lain dalam lingkup sosial termasuk hubungannyadengan lingkungan alam dan hubungan manusia dengan Tuhannya (Nurgiyantoro, 2010: 323-324).

Dongeng telah menjadi bagian dalam proses pendidikan yang diperkenalkan sejak masih usia dini. Dongeng digunakan sebagai media komunikasi dari orang tua kepada anakanaknya untuk mendidik dan menghibur. Dongeng-dongeng yang diceritakan atau dibacakan itu memberikan pesan-pesan moral bagi perkembangan perilaku anak.

Cerita fabel merupakan dongeng tentang kehidupan binatang yang berperilaku menyerupai manusia. Fabel termasuk jenis cerita fiksi, bukan kisah tentang kehidupan nyata.Cerita fabel sering juga disebut cerita moral karena pesan yang ada didalam cerita fabel berkaitan erat dengan moral.

Binatang-binatang yang ada pada cerita fabel memiliki karakter seperti manusia. Karakter mereka ada yang baik dan ada juga yang tidak baik. Mereka mempunyai sifat jujur, sopan, pintar dan senang bersahabat, serta melakukan perbuatan terpuji. Mereka ada yang berkarakter licik, culas, sombong, suka menipu, dan ingin menang sendiri. Cerita fabel menjadi salah satu sarana potensial dalam menanamkan nilai-nilai moral pada anak-anak

Buku cerita anak dalam bahasa Inggris, apalagi yang ditujukan untuk meningkatkankemampuananakdalam berbahasaInggrismemilikibeberapahal penting. Selain ilustrasi,gambar yang menarik, buku cerita bahasa Inggris untuk anak memuat aspek kebahasaannya juga. Apakah bahasa Inggris di dalam cerita itu memang sesuai untuk anak? Bagaimana isi cerita anak itu? Apakah ada nilai positif bagi anak dari cerita itu? Bagaimana pencitraan karakter di cerita anak? Bagaimana pengaruh cerita anak terhadap perkembangan kepribadian anak? Apakah cerita memberikan pengaruh yang positif terhadap anak? Apakah cerita anak sudah memperhatikan perkembangan anak? Bertolak dari pertanyaan-pertanyaan sederhana itu, kegiatan penelitian bermaksud untuk mengetahui lebih dalam aspek-aspek wacana dalam cerita anak yang dapat digunakan untuk pengajaran bahasa Inggris sebagai bahasa asing.

Menganalisis cerita-cerita tersebut sudah seharusnya tidak terbatas pada aspek surface structure sekedar melihat susunan kata-kata yang tertata. Lebih dari itu kandungan cerita yang kaya harus dilihat lebih dalam lagi. Unsur-unsur yang berhubungan dengan konteks terjadinya peristiwa perlu dilihat untuk menangkap makna yang lebih komprehensif dari cerita-cerita itu.

Oleh karenanya, analisis wacana diperlukan supaya penikmat cerita dapat mengerti tidak hanya aspek bentuk dan makna dari teks tertulis tersebut tapi juga konteks yang 
melingkupi karya yang diteliti. Analisis wacana memungkinkan orang mengetahui sesuatu di balik yang tertulis. Melalui analisis wacana diperoleh penafsiran mengenai konteks-konteks yang melingkupi suatu karya. Konteks-konteks itu dapat muncul dalam konteks kultural, situasi, fisik, epistemis, dan konteks sosial. Semua konteks itu berjalin berkelin dan membentuk hubungan membangun satu wacana utuh mengenai anak.

Anak-anak bukanlah orang dewasa. mereka memiliki karakteristik sendiri. Menurut Slattery dan Willis (2001) anak- anak sedang mengalami perkembangan fisik dan psikologi yang pesat dan diliputi rasa ingin tahu yang tinggi. Anak-anak suka belajar dengan berbagai cara. Mereka suka bermain dan berimajinasi. Selain itu, mereka memahami situasi dengan petunjuk nonverbal, bukan dengan penjelasan tentang bahasa. Dalam segi ini, aspek gambarpun memainkan peran penting dalam penyampaian makna. Dalam makalah ini, aspek multimodalitas akan digunakan dalam menganalisis teks yang ada.

\section{KAJIAN TEORI}

Dongeng merupakan salah satu dari bagian folklor selain mite (mitos) yang didefenisikan oleh Poerwadarminto (dalam Handajani, 2008:13) sebagai:

Cerita tentang kejadian zaman dahulu yang aneh-aneh atau cerita yang tak terjadi. Dongeng diceritakan terutama untuk hiburan walaupun banyak juga melukiskan tentang kebenaran, berisikan pelajaran (moral), bahkan sindiran. Pengisahan dongeng mengandung harapan-harapan, keinginan-keinginan, dan nasihat baik yang tersirat maupun tersurat.

(http:// awanadec. wordpress.com/2011/05/13/dongeng-sebagai-media-

\section{belajar/)}

Oleh karena keselarasan antara folklor dan dongeng maka dapat dikatakan bahwa dongeng adalah produk budaya yang tidak dapat dipisahkan dari masyarakat. Mitos-mitos itu dapat mirip satu dengan yang lain, karena adanya yang disebut Carl Gustav Jung sebagai kesadaran bersama yang terpendam pada setiap umat manusia yang diwarisinya secara biologis (Rafiek, 2012:55). Itulah sebabnya tema-tema dongeng yang sama bisa bermunculan di berbagai tempat dan masa yang berbeda. Kita dapat menemui tema putri diselamatkan pangeran, kurcaci, orang tua bijaksana, dan sejumlah tema lainnya, muncul secara berulang di berbagai tempat dan sepanjang rentang masa.

Melalui cerita, seorang penulis mengkomunikasikan gagasannya kepada pembaca. Komunikasi yang terbangun di antara keduanya disampaikan dalam bentuk kode-kode bahasa 
atau ujaran pada konteks tertentu. Dalam peristiwa seperti ini, istilah wacana dapat dimunculkan.

Wacana adalah satuan bahasa yang lengkap, sehingga dalam hierarki gramatikal merupakan satuan gramatikal tertinggi atau terbesar (Chaer dalam Sumarlam (2003). Dalam wacana terdapat ekpresi ide yang umumnya di atas level kalimat yang memiliki kohesi dan koherensi se- hingga pesan yang ada dapat dipahami oleh pihak - pihak yang melakukan komunikasi.

Ide ini sejalan dengan pendapat J.S. Badudu (dalam Eriyanto (2001: 2). Wacana oleh Badudu dinyatakan sebagai kesatuan bahasa yang terlengkap dan tertinggi atau terbesar di atas kalimat atau klausa dengan koherensi dan kohesi yang tinggi yang berkesinambungan, yang mampu mempunyai awal dan akhir yang nyata, disampaikan secara lisan atau tertulis.

Penulis dongeng juga bersinggungan dengan wacana di saat menyampaikan gagasannya lewat karya sastra yang dihasilkannya. Cerita yang ditulis misalnya, tidak bisa dilepaskan dari aspek wacana. Dalam cerita, selain terdiri dari rangkaian kata-kata, padanya juga memuat konteks jamannya. Isi cerita merefleksikan fenomena sosial di waktu tertentu. Sehingga mendiskusikan isi cerita seharusnya tidak hanya aspek bentuk tapi juga makna dan konteksnya.

Multimodalitas berkaitan dengan semiotik. Dikatakan berkaitan karena menurut Iedema (2003) Multimodalitas atau multimodality dapat juga dikatakan sebagai "istilah teknis yang bertujuan menunjukkan bahwa pemaknaan yang kita lakukan selama ini memanfaatkan beragam semiotik". Sementara Liu (2013) memaknai multimodalitas sebagai "aturan dan prinsip analisis yang membantu pembaca memahami hal-hal seperti penempatan elemenelemen dalam gambar, bingkai, salience, saturasi warna, serta tampilan gambar secara keseluruhan." Multimodalitas dikatakan sebagai sebuah pendekatan interdisipliner yang memandang komunikasi dan juga representasi. Pendekatan multimodal menyediakan konsep, metode, dan kerangka untuk mengumpulkan dan menganalisis data visual, aural, dan aspekaspek lain dalam interaksi (Bezemer, 2012). Sedangkan Kress dan van Leeuwen (2006) mendefinisikan multimodality sebagai:

Language, whether in speech or writing, has always existed as just one mode in the totality of modes involved in the production of any text, spoken or written. A spoken text is not just verbal but also visual, combining with 'non-verbal' modes of communication such as facial expression, gesture, posture and other forms of self-presentation. 
Multimodalitas dapat dipahami sebagai sebuah 'prosedur analisis' yang menggabungkan alat dan langkah analisis linguistik seperti misalnya systemic functional linguistics (SFL), atau Tata Bahasa Fungsional, dengan alat analisis untuk memahami gambar, bila teks yang dianalisis menggunakan dua modes, verbal dan gambar.

Dewasa ini, penggunan mode berbeda semakin banyak digunakan untuk menyampaikan pesan. Penyampaian pesan, bukan saja tindak tutur dari sang penutur kepada penerima, tapi juga usaha penawaran makna dari pembuat pemaknaan kepada audiens, termasuk di dalamnya konsumen seperti dalam iklan sebuah produk. Sementara mode menurut Bezemer dan Kress (2008) adalah " a socially and culturally shaped resource for making meaning", mode dipahami sebagai sumber yang terbentuk secara sosial dan budaya untuk mengomunikasikan makna. Sumber ini tidak terbatas pada bahasa saja sebagai sumber yang tidak asing dan biasa digunakan, tapi juga dapat dirujukkan pada gambar, bunyi, spasi/ruang yang dengannya orang menyampaikan pesan dan menawarkan makna. Diantara mode berbeda yang digunakan orang secara bersamaan dalam sebuah teks untuk mengomunikasikan pesan mereka, mungkin gabungan verbal dan citraan atau gambar yang paling sering digunakan, dibandingkan kombinasi mode berbeda lainnya seperti misalnya verbal dan musik.

Dalam kaitannya dengan alat analisis teks multimodal, khususnya yang menggabungkan verbal dan visual, Kress dan van Leeuwen (2006) menawarkan apa yang dianggap sebagai 'tata bahasa' gambar. Mereka menggagas 'tata bahasa' gambar menggunakan perspektif bahasa. Menurut mereka, teks di luar bahasa seperti terutama gambar, desain, atau ilustrasi, menjadi milik kalangan tertentu yaitu para desainer atau ilustrator yang memiliki akses terhadapnya. Para desainer dan ilustrator ini, dalam pandangan Kress dan van Leeuwen, tidak memiliki cara untuk menyampaikan pengetahuan mereka dalam bahasa yang dipahami mereka yang berada di luar lingkarannya.

Lebih lanjut, perpaduan tata bahasa dan sintaksis dengan elemen lain dapat menghasilkan makna yang lebih menyeluruh (Kress \& van Leeuwen 2006, p.1). Sebagaimana tata bahasa pada umumnya yang medeskripsikan kombinasi kata dalam sebuah klausa, kalimat atau teks, 'tata bahasa' gambar akan mendeskripsikan berbagai elemen seperti orang, tempat, dan sesuatu yang dikombinasikan dengan 'pernyataan' visual.

Bersandar pada Halliday $(1994,2004)$ yang melihat tata bahasa tidak sebagai aturan tapisebagai sumber untuk membuat dan menyampaikan makna, Kress dan van Leeuwen melihatbahwa gambar dapat 'diperlakukan' seperti bahasa. Bila demikian, maka gambar 
dapat memiliki 'tata bahasa' yang dengannya orang dapat membaca gambar dengan 'benar' untuk mengungkap makna yang disampaikan. 'Tata bahasa' ini kemudian banyak dianggap sebagai dasar penting kerangka analisis multimodality,

\section{TEMUAN DAN PEMBAHASAN}

\section{Analisis Makro}

Sinopsis:

Dalam kisah ini dikisahkan, dahulu kala Kura-kura tinggal di gunung. Gunung tersebut kerap diliputi mendung dan udara dingin. Hal itu membuatnya selalu bersembunyi dalam gua. Kura-kura bosan hidup di gunung dan memutuskan untuk menjelajah dunia lain. Suatu hari, kura kura memutuskan turun gurung.Ia menelurusi aliran sungai dan menemui berbagai binatang dan tumbuhan- ada yang menyenangkan ada pula yang menakutkan.

Diperjalanan ia bertemu anak binatang yang lucu, menyenangkan, bahkan menakutkan. Kura-kura itu bertemu banyak binatang yang menasehatinya agar selalu berhati-hati dalam perjalanannya. Ketika tiba di hutan dan sungai, kura kura di musuhi dan diusir oleh para penghuninya. Dan sang kura kura pun meneruskan perjalanannya. Di tengah perjalanan, tiba tiba hujun turun amat lebatnya dan mengakibatkan air sungai meluap sehingga menyebabkan banjir. Sang kura-kura pingsan dan hanyut terbawa arus hinga ratusan kilometre jauhnya. Ketika siuman, ia mendapati dirinya berada di lautan luas. Binatang laut menerimanya dengan tangan terbuka. Kura-kura pun amat senang berada di dasar lautan yang indah. Namun tidak semua penghuni laut menyukainya. Banyak pula binatang yang tidak menyukainya dan mengusirnya. Suatu ketika, binatang-binatang yang memusuhinya tertangkap jarring nelayan. Sang kura-kura pun tidak berdiam diri dan menolong mereka dengan cara menggigit jaringnya. Merasa berhutang budi pada kura-kura, para penghuni laut pun kini menerima kura-kura dengan tangan terbuka, dan kura kura kini menjadi penjaga samudra.

Moral cerita ini memang bukan tentang indahnya petualangan, melainkan perbuatan baik pasti akan memetik hasil yang manis pula.

Sinopsis ini disusun oleh penulis setelah membaca bukunya beberapa kali dan berusaha mengungkap esensi cerita dari buku itu. Sinopsis ini disusun berdasarkan tujuan dari makalah ini. 
Latar Belakang Penulis:

Penulis (dan penerjemah) buku cerita ini adalah Bambang Joko Susilo, lahir di Sragen, Jawa Tengah, 14 Juli 1964, merupakan penulis yang produktif. Tulisannya menghiasi harian lokal dan nasional. Selain itu, banyak pula karyanya yang diterbitkan oleh beberapa penerbit. Sejumlah penghargaan di bidang penulisan juga pernah diraih oleh bambang Joko Susilo. Sekolah terakhirnya adalah di Sekolah Tinggi Publisistik Jakarta (IISIP), jurusan Ilmu Jurnalistik.

\section{Praktik Diskursif:}

Paparan praktik diskursif yang ada pada buku ini juga berdasarkan pada elaborasi yang ada pada bagian sinopsis dan latar belakang penulis. Buku ini merupakan buku asli/original hasil pemikiran penulisnya, yang juga sebagai penerjemahnya. Jadi cerita pada buku ini tidak bersifat adaptasi dari cerita lain yang sudah ada sebelumnya. Namun, penggambaran unsurunsur pendukung pada buku ini merupakan pengaruh dari adaptasi yang dialami oleh penulis.

Meskipun buku ini dwibahasa (Indonesia - Inggris), buku ini terutama ditujukan untuk anak-anak Indonesia. Sepertinya, tujuan Bambang menulisnya dalam dwibahasa adalah tidak hanya agar anak-anak Indonesia menikmati dan menangkap pelajaran dari ceritanya namun juga agar anak-anak Indonesia mengenal bahasa Inggris sejak dini.

Kura-kura dan penyu adalah hewan bersisik berkaki empat yang termasuk golongan reptil. Bangsa hewan yang disebut (ordo) Testudinata (atau Chelonians) ini khas dan mudah dikenali dengan adanya 'rumah' atau batok (bony shell) yang keras dan kaku. Dalam bahasa Indonesia, kita mengenal tiga kelompok hewan yang termasuk bangsa ini, yalah penyu (bahasa Inggris: sea turtles), labi-labi atau bulus (freshwater turtles), dan kura-kura (tortoises). Dalam bahasa Inggris, dibedakan lagi antara kura-kura darat (land tortoises) dan kura-kura air tawar (freshwatertortoises atau terrapins). (Wikipedia Indonesia)

Kura-kura hidup di berbagai tempat, mulai daerah gurun, padang rumput, hutan, rawa, sungai dan laut. Sebagian jenisnya hidup sepenuhnya akuatik, baik di air tawar maupun di lautan. Kura-kura ada yang bersifat pemakan tumbuhan (herbivora), pemakan daging (karnivora) atau campuran (omnivora).

Kura-kura secara tradisional merupakan hewan yang akrab dengan manusia. Mitologi Hindu menyebutkan bahwa bumi ini disangga oleh empat ekor kura-kura. Demikian pula, kisah kuno Adiparwa menceritakan bahwa kura-kura raksasa berperan penting menyangga 
gunung, yang diputar dan digunakan untuk mengaduk lautan, dalam mencari tirta amerta -air kehidupan. (Chin, 2009)

Setelah membaca cergam ini secara saksama, peneliti menemukan beberapa keganjilan dalam cergam ini. Peneliti menyoroti tiga point keganjilan dalam cergam ini. Pertama, dalam cergam ini digambarkan seekor kura-kura yang berasal dari daratan dan bermigrasi ke lautan. Kedua, diceritakan pula jika terancam bahaya, sang kura-kura tersebut akan bersembunyi dibalik tempurungnya. Terakhir, dalam cergam ini, kura-kura diterjemahkan menjadi turtle dalam teks bahasa Inggrisnya. Mengapa tiga hal tersebut yang menjadi sorotan dari peneliti?

Banyak orang sulit membedakan antara Kura-kura, bulus, dan penyu. Kura-kura, bulus, dan penyu merupakan reptil anggota dari ordo chelonia. Hewan-hewan ini telah hidup di bumi sejak 220 tahun yang lalu, sejaman dengan dinosaurus yang menguasai dunia kala itu. Saat kita mendengat kata kura-kura, bulus, dan penyu terkadang kita bingung apa sebenarnya perbedaan mereka semua, apa dasar yang dijadikan perbedaan nama tersebut?

Kura-kura mengacu kepada chelonia yang hidup di darat, dalam bahasa inggris disebut dengan tortoise. Mereka hidup di darat dengan memakan dedaunan, buah yang jatuh ke permukaan tanah dan hewan-hewan kecil yang bergerak lambat. Kura-kura biasanya bergerak lambat dan hidup di tempat kering, walaupun beberapa jenis juga ditemukan di hutan hujan tropis. (http://www.edubio.info/)

Bulus merupakan chelonia yang menghabiskan sebagian besar waktunya di air tawar, dalam bahasa inggris mereka disebut terrapin. Mereka naik ke darat untuk berjemur dan bertelur, mencari makan di air dengan memakan rerumputan maupun hewan air yang dapat ditemukannya. Bahkan ketika tidur hewan ini sering tetap berada di air dan mengambang di permukaan air. Untu membantunya berenang, bulus memiliki selaput renang diantara jari kakinya. (http://www.edubio.info/)

Penyu merupakan chelonia yang hidup di laut, dalam bahasa inggris disebut sebagai turtle. Mereka menghabiskan sebagian besar waktunya di laut, hanya ke pantai saat akan bertelur saja. Mayoritas penyu merupakan pemakan rumput laut dan alga, namun beberapa spesies lebih menyukai ubur-ubur sebagai makanan utamanya. Karena hidup di laut, penyu tidak memiliki jari pada tungkainya. Mereka memiliki tungkai yang berbentuk seperti sirip ikan yang berguna sebagai penggerak di air. (http://www.edubio.info/)

Ditambahkan pula dalam situs tersebut bahwa ketiga jenis chelonia ini memiliki pertumbuhan yang lambat. Penyu dan bulus dapat bergerak cukup cepat apabila berada dalam air. Namun saat di darat mereka bergerak dengan lambat sehingga mudah ditangkap oleh 8 
pemangsa. Chelonia memiliki tempurung keras yang berfungsi sebagai pelindung tubuh. Tempurung bagian atas yang menggelembung biasa disebut dengan istilah karapaks, sedangkan bagian bawah yang mendatar disebut plastron. Kura-kura dan bulus dapat memasukkan kepalanya ke dalam tempurung sebagai perlindungan, sedangkan penyu tidak dapat melakukan itu karena tidak memiliki spasi dalam tempurungnya.

Penjabaran perbedaan antara kura-kura, bulus dan penyu diatas dapat membantu memberikan penjelasan atas sorotan peneliti. Pertama, dalam cergam ini digambarkan seekor kura-kura yang berasal dari daratan dan bermigrasi ke lautan. Sedangkan berdasarkan scientific fact yang dijabarkan diatas, Kura-kura mengacu kepada chelonia yang hidup di

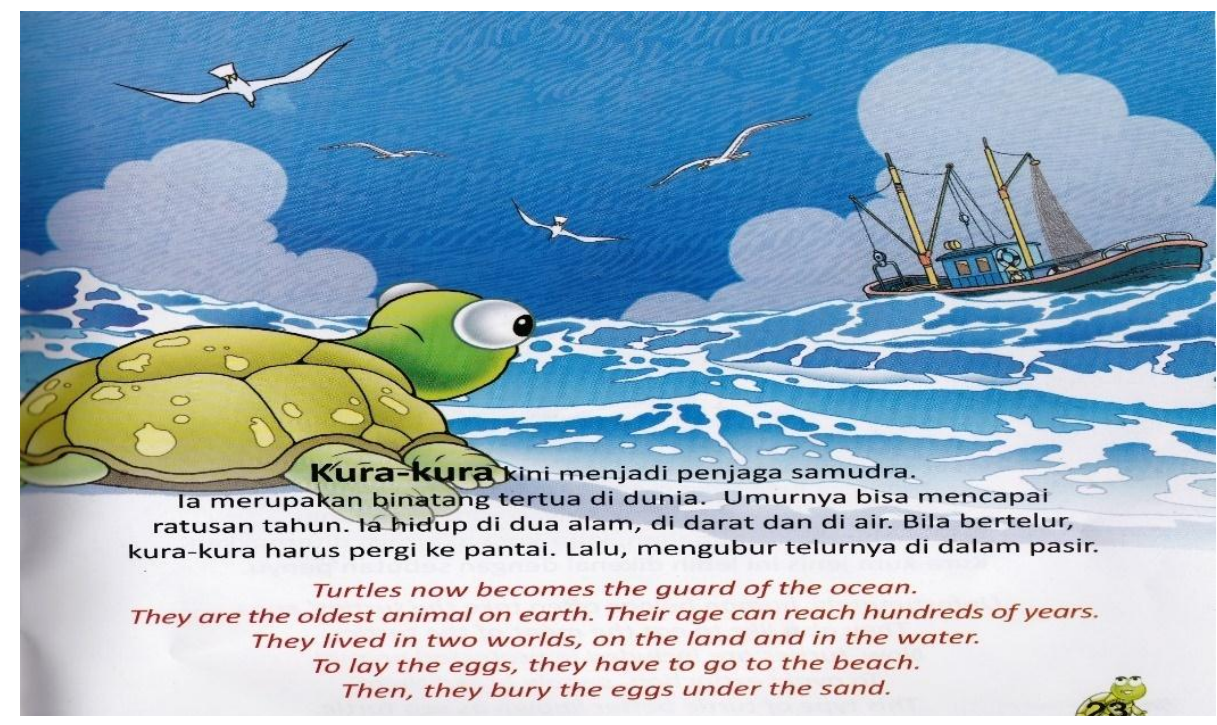

Gambar 3.1.1: Penyu yang tergambar sebagai kura-kura

darat, Bulus merupakan chelonia yang menghabiskan sebagian besar waktunya di air tawar, dan Penyu merupakan chelonia yang hidup di laut. Dalam cergam ini dikisahkan bahwa sang kura-kura bermula hidup di daratan kemudian mengembara dan menghabiskan waktu di sungai air tawar dan terakhir menghabiskan sisa hidupnya di lautan dan sesekali pergi kedaratan untuk bertelur. Berdasarkan scientific fact disini, terdapat pertentangan makna. Apakah benar yang diceritakan ialah kura-kura? Jika memang kura-kura mengapa ia menghabiskan waktu yang cukup lama di sungai air tawar? Terlebih di akhir cerita digambarkan ia menjadi penjaga lautan dan menghabiskan sisa hidupnya di lautan walau terkadang ke daratan untuk bertelur, yang notabene merupakan ciri khas dari penyu (gambar 3.1.1)

Sorotan yang kedua, diceritakan pula jika terancam bahaya, sang kura-kura tersebut akan bersembunyi dibalik tempurungnya. Padahal menurut kutipan scientific fact diatas dijelaskan bahwa kura-kura dan bulus dapat memasukkan kepalanya ke dalam tempurung 
sebagai perlindungan, sedangkan penyu tidak dapat melakukan itu karena tidak memiliki spasi dalam tempurungnya. Dalam hal ini, penggambaran kura-kura dalam cerita dirasa tepat karena memang kura-kura lah yang dapat memasukan anggota tubuh ke dalam tempurungnya.

Sorotan yang ketiga, kura-kura diterjemahkan menjadi turtle dalam teks bahasa Inggrisnya. Menurut sumber situs http://www.edubio.info/ dijelaskan bahwa bahasa Inggris dari kura-kura ialah tortoise, bulus adalah terrapin, dan penyu adalah turtle. Untuk memperkuat pernyataan ini, peneliti membuka kamus oxford advanced learner (Hornby, 2008). Disini dijelaskan bahwa tortoise ialah a reptile with a hard round shell that lives on land and moves very slowly. It can pull its head and legs into its shell. Sementara terrapin ialah $a$ reptile with a hard round shell that lives in warm rivers and lakes. Sedangkan turtle ialah a large reptile with a hard round shell that lives in the sea.Dalam hal ini, pilihan kata yang digunakan oleh penulis dirasa kurang tepat jika memang mengacu pada kura-kura. Jika penulis mengacu pada hewan yang tinggal di lautan dan sebagai sang penjaga samudra, maka padanan yang ia pilih cukup tepat. Namun jika mengacu pada kemampuan hewan itu melindungi diri dan pilihan kata bahasa Indonesia yang digunakannya, maka pilihan kata turtle dirasa tidak tepat.

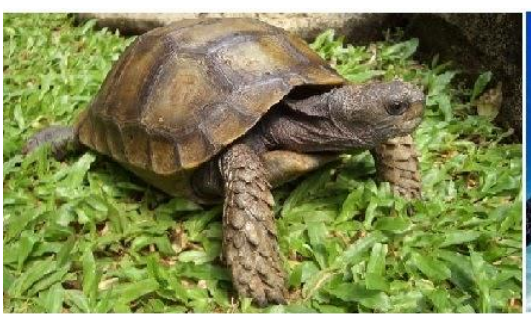

KURA-KURA

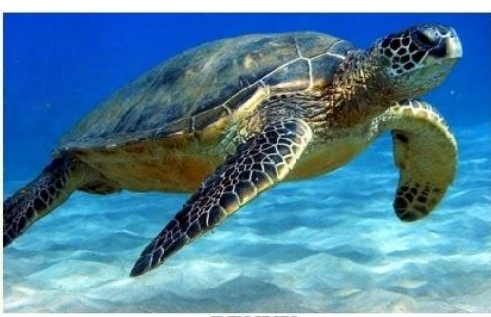

PENYU

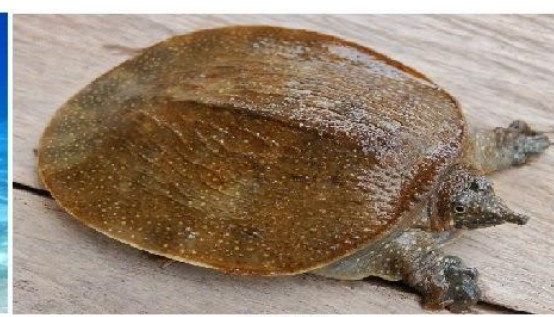

BULUS

Gambar 3.1.2: Perbedaan kura-kura, penyu, dan bulus (sumber http://www.dyankuya.com/2015/01/perbedaan-kura-kura-penyu-dan-bulus.html)

Berdasarkan penjabaran diatas, terdapat ketidak konsistenan dalam pemilihan kosa-kota maupun jenis hewan yang diceritakan. Peneliti menyimpulkan bahwa penulis mencampur adukan habitat, kemampuan maupun bentuk dan istilah dalam cerita agar mempermudah anak-anak dalam mengenal hewan yang termasuk dalam ordo Chelonians ini. Karena memang untuk membedakan ketiga jenis hewan tersebut dirasa cukup sulit untuk anak kecil. Tujuan pencampur-adukan ini bisa juga dikarenakan tujuan penulis agar dapat menyusun cerita yang kaya imajinasi. Sementara untuk penggunaan padanan bahasa sasaran yang 
kurang tepat peneliti berasumsi hal itu dikarenakan latar belakang penulis yang tidak memiliki latar belakang pendidikan berbahasa Inggris.

Jika menganalisis penggambaran bentuk dan rupa kura-kura dalam cerita ini, baik melalui struktur tempurung maupun bentuk kaki, cerita ini memang menggambarkan kurakura sebagai tokoh utama (gambar 3.1.3).

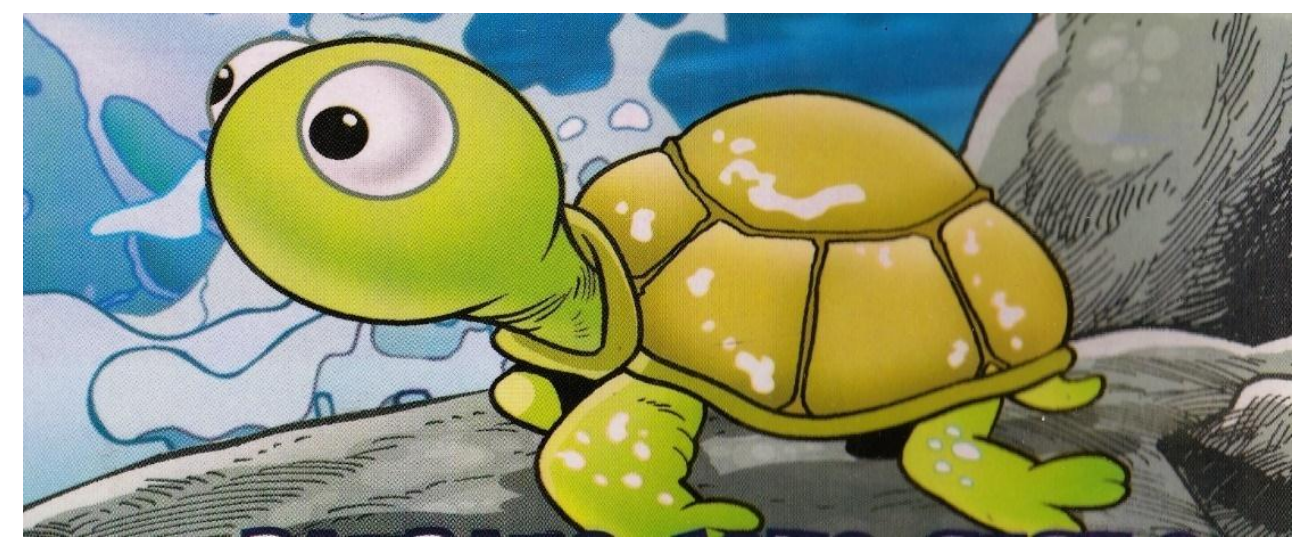

Gambar 3.1.3: Penggambaran sang kura-kura dalam cergam Kura-kura si penjaga samudra

\section{Analisis Mikro}

Analisis karakter melalui pendekatan multimodalitas:

Teks Cergam ini secara keseluruhan terdiri dari 24 halaman. Kura-kura dalam cergam ini tidak memiliki nama, dan hanya digambarkan dengan nama kura-kura, sementara dalam bahasa inggrisnya digambarkan dengan nama turtle. Kura-kura adalah seekor hewan yang mana seharusnya memakai it sebagai referennya. Namun, dalam kisah ini, penulis menempatkan kura-kura setingkat dengan manusia karena menggunakan he sebagai referennya. Penggunaan pronomina he sebagai penanda kohesi yang mengacu pada sang kura-kura dalam versi bahasa Inggrisnya juga bisa disimpulkan bahwa kura-kura pada cerita ini digambarkan sebagai kura-kura jantan. 


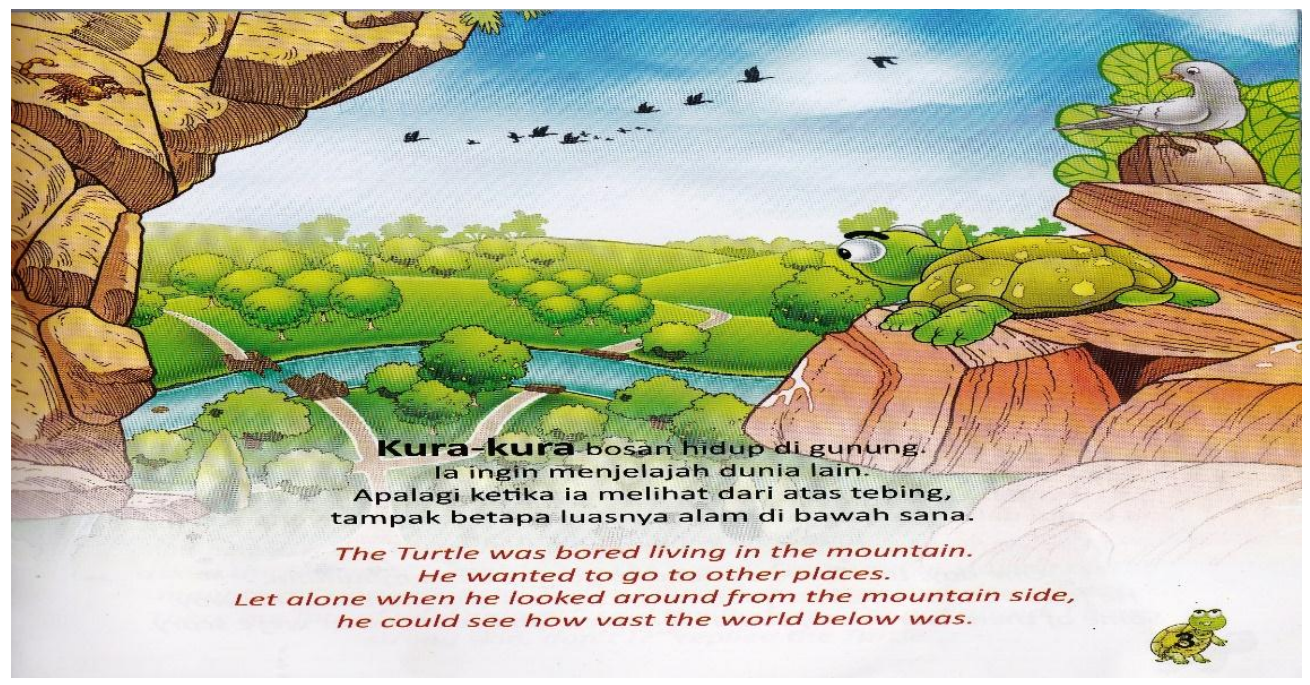

Gambar 3.2.1: kebosanan sang kura-kura

Pada bagian awal cergam ini (gambar 3.2.1), digambarkan seekor kura-kura yang tinggal di atas gunung dan merasa bosan dengan kehidupan di gunung. Ia melihat indahnya daratan dari atas tebing. Dari sudut pandang multimodalitas, kebosanan sang kura-kura tergambar dalam ekspresi datar dalam raut wajahnya. Penggambaran gunung dalam cergam ini ditampilkan oleh tumpukan bebatuan yang terkesan monoton dan sang kura-kura sedang melihat luasnya alam dari ketinggian. Alamnya digambarkan dengan banyaknya pepohonan dan rerumputan hijau serta birunya aliran sungai yang menyejukan. Hal ini lah yang kemudian mengambarkan bahwa kura-kura merasa tergoda untuk turun gunung. Jika menilik dari penjabaran analisis makro, benar adanya jika kondisi alam ini menggambarkan kurakura, karena berlatarkan pada daratan. Pada versi bahasa sasarannya, bahasa Inggris, semua unsur tersebut dapat disampaikan degan baik. Namun, kata tebing diterjemahkan dengan padanan yang kurang tepat, yaitu mountain side. Padanan kata yang akurat untuk tebing adalah "steeply sloping riverbank or mountain side." (Sadily dan Echols, 2002). Sehingga, dalam hal ini penerjemah melakukan pergeseran makna karena adanya penghilangan kata. 


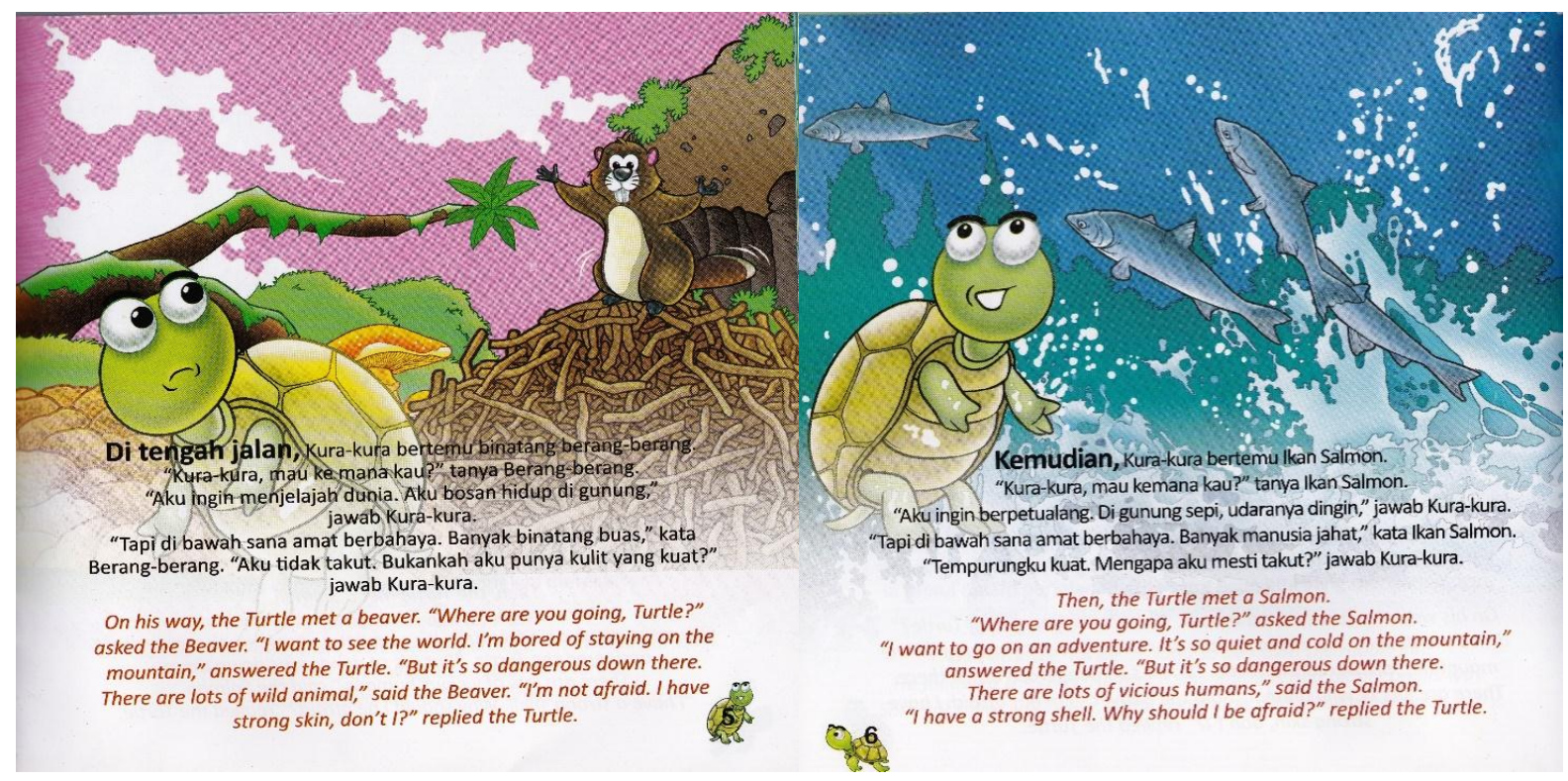

Gambar 3.2.2 dan 3.2.3: Pemunculan karakter berang-berang dan ikan salmon

Ketika sedang menelusuri jalan, sang kura-kura bertemu dengan berang-berang dan ikan salmon. Disini, digambarkan sang berang-berang dan ikan salmon adalah binatang yang baik, karena memberikan nasihat yang baik kepada kura-kura. Dari sudut pandang multimodalitas, kesan baik itu dapat tersampaikan karena mimic dan raut muka binatang tersebut memang terkesan ramah. Dari scene ini, dapat pula kita simpulkan sifat keberaninan dari kura-kura, ujaran "aku tidak takut. Bukankah aku punya kulit yang kuat?" serta ujaran ketika bertemu dengan ikan salmon "Tempurungku kuat, mengapa aku mesti takut?" Raut muka dan mimic wajah sang kura-kura pun terlihat yakin dan berani. Hal ini berarti penggambaran ilustrasinya pun menyampaikan makna yang ingin disampaikan. Ujaran yang penuh keyakinan ini dapat di terjemahkan dengan baik. Sang berang-berang menyapa dengan kalimat tanya "Kura-kura, mau ke mana kau?" yang diterjemahkan ke dalam bahasa sasaran menjadi kalimat tanya juga "Where are you going, turtle?".Jika menilik dari penjabaran analisis makro, penggambaran latar ini lebih tepat jika sang tokoh utama ialah bulus. Karena mengambil setting sungai sebagai latarnya. (gambar 3.2.2 dan 3.2.3) 


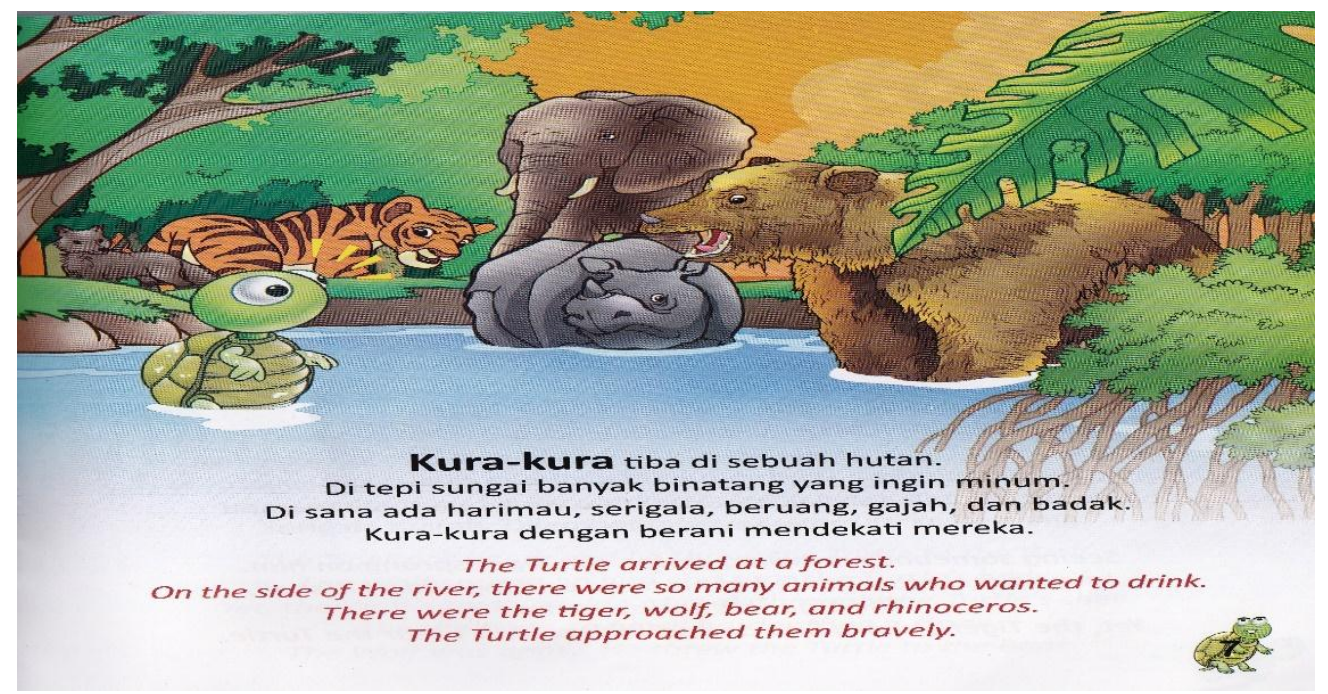

Gambar 3.2.4: Kura-kura tiba di Hutan

Penggambaran bahwa sang kura-kura ini adalah kura-kura yang pemberani semakin kentara pada gambar 3.2.4. Walau ada banyak binatang buas yang sedang minum di tepi sungai, kura kura dengan berani mendekati mereka. Dari sudut pandang multimodalitas, binatang-binatang buas tersebut digambarkan dengan ekspresi penggambaran yang menyeramkan. Terlihat sang beruang sedang mengaum ke arah kura-kura, atau tatapan mata sang serigala yang menyipit. Walau penggambaran harimau agak kurang tepat karena tidak memunculkan kesan seram. Frasa tepi sungai diterjemahkan menjadi on the side of the river. Padanan ini dinilai agak kurang tepat, karena dalam bahasa inggris terdapat kosakata yang lebih tepat yaitu riverbank (Sadily dan Echols, 2002)

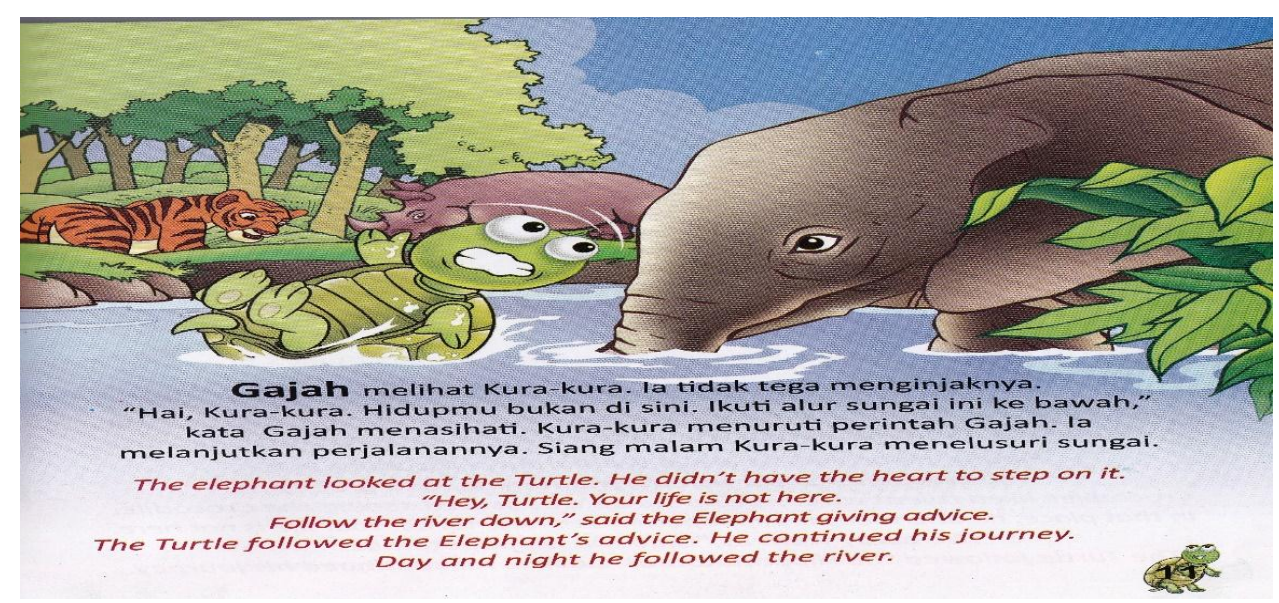

Gambar 3.2.5: Sang kura-kura sedang dinasehati sang gajah

Beruang, Harimau, dan Serigala digambarkan sebagai hewan yang buas dikarenakan menyerang sang krua-kura. Lain halnya dengan sang gajah. Sang gajah dalam kisah ini tergambar sebagai hewan yang baik hati karena tidak ikut menyerang sang kura-kura, dan 
bahkan memberikan nasihat kepada kura-kura untuk melanjutkan perjalanan. Penerjemahan ungkapan tidak tega menjadi did not have the heart dirasa cukup tepat. (gambar 3.2.5)

Latar cerita berganti kedalam lautan. Yang mana seharusnya bukanlah habitat bagi kura-kura, tetapi habitat bagi penyu.

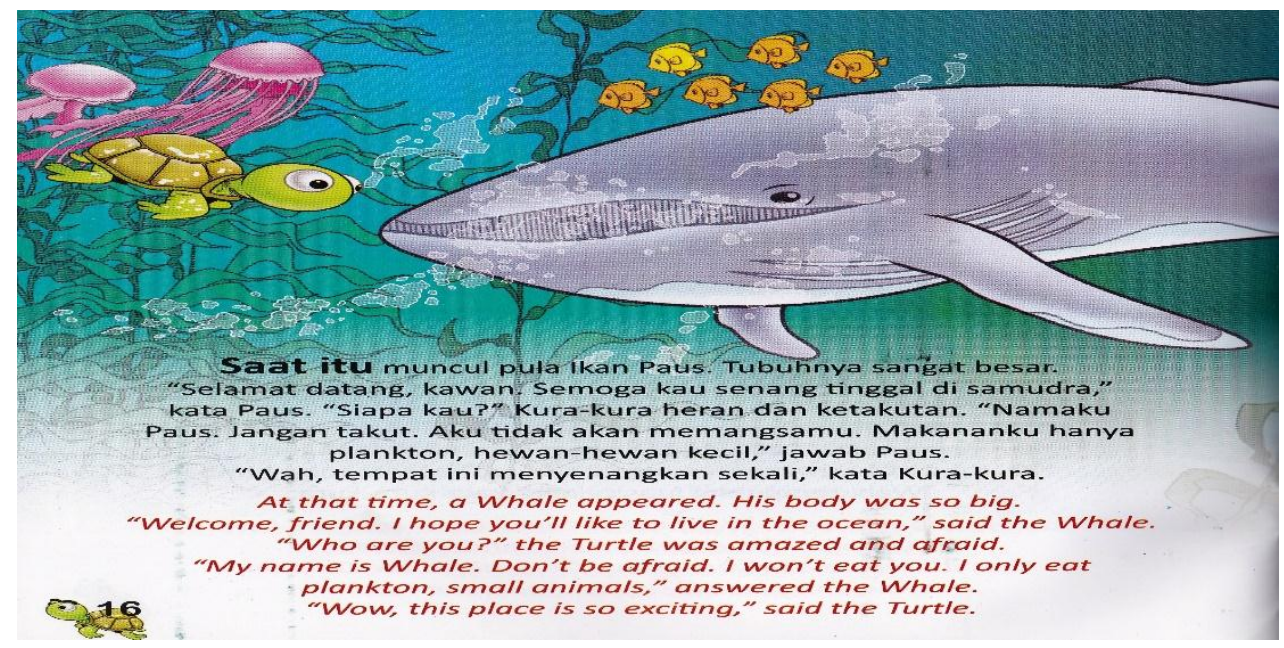

\section{Gambar 3.2.6: Kedatangan sang kura-kura disambut oleh Paus}

Ikan paus pada cerita ini digambarkan sebagai hewan yang baik hati. Hal ini merujuk pada ujaran-ujaran ikan paus; "selamat datang, kawan. Semoga kau senang tinggal di samudra," dan "namaku paus, jangan takut. Aku tidak akan memangsamu. Makananku plankton, hewan-hewan kecil," penggunaan kata kawan, yang diterjemahkan menjadi friend, menandakan bahwa sang ikan paus hendak membangun kedekatan dengan kura-kura. Konteks intimacy yang dibangun paus ialah konteks pertemanan, selain dengan penggunaan kosakata kawan tadi, sang paus pun mengucapkan selamat dating yang benandakan paus disini ialah hewan yang ramah. Raut mata dan senyum yang terpancar dari sang paus mencerminkan keramahannya. Dengan adanya ikan-ikan yang mengelilinya pun membuktikan bahwa ia memang hewan yang disenangi, atau setidaknya menggambarkan ia memang tidak memakan selain plankton (gambar 3.2.6). 


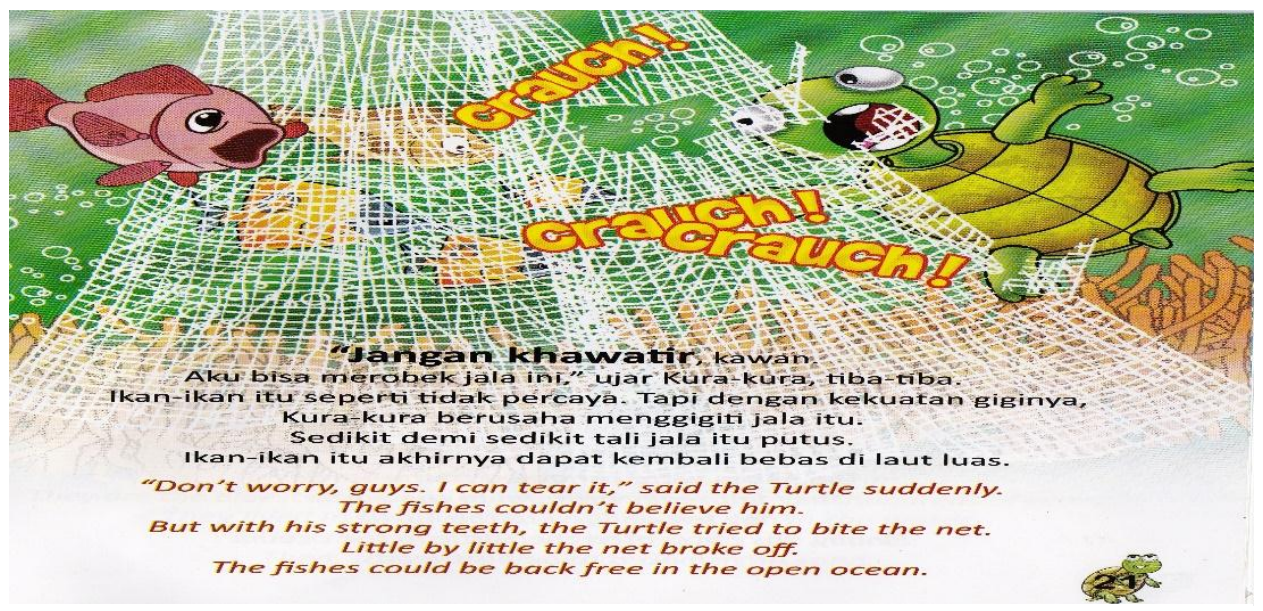

Gambar 3.2.7: Aksi Heroik sang kura-kura

Penggambaran karakter sang kura-kura yang lain terlihat pada gambar 3.2.7. sang kurakura merupakan sosok yang pemaaf dan suka menolong. Pada adegan ini, kura-kura sedang berusaha menolong para hewan laut yang terperangkap jarring nelayan. Sang kura-kura, yang sebelumnya diusir oleh para mahluk laut tersebut, tidak memiliki perasaan dendam dan segera menolong mereka dengan cara menggigit jala nelayan. Dalam gambar, dapat dilihat jala sang nelayan berlubang digigit sang kura-kura. Terdapat pula seekor ikan merah yang terbebas dari jeratan jala sembari memperlihatkan ekspresi kelegaan. Dalam gambar juga terdapat kata-kata "crauch!" yang mungkin untuk memunculkan efek suara gigitan sang kura-kura. Penggunaan kata crauch terkesan dinaturalisasikan kedalam bahasa inggris, karena biasanya efek suara gigitan dalam bahasa Indonesia yang umum digunakan ialah krauk. Dalam adegan ini, sekali lagi kura-kura memperlihatkan sifat keberaniannya. Tanpa rasa takut sang kura-kura mendekati jala sang nelayan. Keyakinan atau kepercayaan dirinya juga dapat dilihat dari ujarannya "jangan khawatir, kawan. Aku bisa merobek jala ini." Terdapat ketidak konsistenan istilah yang digunakan penulis disini. Jika pada adegan sebelumnya sang penulis menggunakan kata friend sebagai padanan dari kata kawan, kali ini penulis menggunakan kata guys sebagai padanan kata kawan.

\section{KESIMPULAN}

Penelitian ini merupakan upaya interdisipliner yang menyediakan investigasi kritis dalam kekuatan bahasa pada tataran analisis makro dan mikro pada media buku cerita dwibahasa anak-anak. Pada analisis makro, Peneliti menyimpulkan bahwa penulis mencampur adukan habitat, kemampuan maupun bentuk dan istilah dalam cerita agar mempermudah anak-anak dalam mengenal hewan yang termasuk dalam ordo Chelonians ini. Karena memang untuk membedakan ketiga jenis hewan tersebut dirasa cukup sulit untuk 
anak kecil. Tujuan pencampur-adukan ini bisa juga dikarenakan tujuan penulis agar dapat menyusun cerita yang kaya imajinasi. Sementara untuk penggunaan padanan bahasa sasaran yang kurang tepat peneliti berasumsi hal itu dikarenakan latar belakang penulis yang tidak memiliki latar belakang pendidikan berbahasa Inggris. Sedangkan dalam tataran analisis mikro, karakter hewan pada cerita fabel memiliki karakter seperti manusia. Cerita fabel menjadi salah satu sarana potensial dalam menanamkan nilai-nilai moral pada anak-anak. Cerita fabel sering juga disebut cerita moral karena pesan yang ada didalam cerita fabel berkaitan erat dengan moral. Berdasarkan analisis yang telah dilakukan dapat disimpulan bahwa penggambaran tokoh utama dalam cerita ini merupakan sosok yang baik hati, pemberani dan tidak pendendam. Aspek-aspek tersebutlah yang ingin ditanamkan penulis ini dalam cergam "Kura-Kura Si Penjaga Samudra" ini. Penulis ingin menanamkan kepada anak-anak bahwa kebaikan dalam hal apapun akan membuahkan hasil yang manis dikemudian waktu.

\section{DAFTAR PUSTAKA}

Bambang Joko Susilo. (2010). Kura-Kura Si Penjaga Samudra. Jakarta: Bestari Kids

Bezemer, J. (2012). What is multimodality. (Retrieved from http://mode.ioe.ac.uk/2012/02/16/what-is-multimodality/)

Chandler, D. (2007). Semiotics The Basic. London and New York: Roudledge.

Duncan, R. \& Smith, M. (2009). The Power of Comics: History, Form, and Culture. New York: Continuum.

Eko. (2007). It's a political jungle out there: how four African newspaper cartoons dehumanized and deteritorialized african political leaders in the post-cold war-era. Sage: 69 (3), pp. 221-222.

Fairclough, N, (1998).Critical Discource Analysis. Longman, London \& New York.

Kress, G. \& van Leeuwen, T. (2006). Reading Images: the grammar of visual design. New York: Routledge

Kwok Chin (2009). Kura-Kura Sebagai Sumber Ide dalam Penciptaan Karya Lukis. Pengantar Karya Tugas Akhir. Solo: UNS Press 
Liu, J. (2013). Visual images interpretive strategies in multimodal texts. Journal of Language Teaching and Reasearch, 4 (6), pp.1259-1263.

Liu, J. (2013). Visual images interpretive strategies in multimodal texts. Journal of Language Teaching and Reasearch.

Burhan Nugriyantoro. (2010). Teori Pengkajian Fiksi. Yogyakarta: UGM Gadjah Mada University Press

Slattey, M. \& J. Willis. (2003). English for Primary Teachers. Oxford: OUP.

Sorensen, L. (2011). A Multimodal approach for advertising for professionals in the film, television and photography business. Retrieved from Department of Language and Business Communication Aarhus School of Business Aarhus University.

Suharianto. (1982). Dasar-Dasar Teori Sastra. Surakarta: Widya Duta.

Sukyadi. (2011). Teori dan Analisis Semiotika. Bandung: Rizki Press.

http://www.dyankuya.com/2015/01/perbedaan-kura-kura-penyu-dan-bulus.html http:// awanadec. wordpress.com/2011/05/13/dongeng-sebagai-media-belajar/) http://www.edubio.info/2014/10/perbedaan-kura-kura-bulus-dan-penyu.html http://id.wikipedia.org/wiki/Kura-kura 